\title{
Legislation on Educational Punishment
}

\author{
Mei Liu \\ Kunming University \\ Kunming, China
}

\begin{abstract}
Theoretically and practically, studies have been mainly made on how to understand the power of educational punishment, the problems existing in the process of educational punishment and how to solve the problems to enable teachers to properly exercise the power and make any punishment educational, which are also the important issues with which modern primary and middle school teachers are faced. To solve this fundamentally, educational punishment must be legalized. On the basis of the overseas and Taiwanese laws on educational punishment, in combination with the practical situation of the secondary and primary education of China, the paper proposes relatively reasonable legislative suggestions on educational punishment.
\end{abstract}

\section{Keywords—educational punishment; legislation; relief}

\section{INTRODUCTION}

As the opposite of reward, punishment, universally existing in educational activities, is considered as an educational mode recognized by parents and the society. In China, educational punishment has generated a great controversy. In the absence of effective regulation by laws, any abuse of the power of educational punishment seriously hurts students physically and mentally; teachers dare not to enforce punishments in any form to protect themselves against any crime subject to corporal punishment.

Without prejudice to the dignity and the physical and mental health of the students who have misconducts, any punishment should be implemented for the purpose of preventing them from misbehaving again. Physically or mentally hurting or fatiguing the students who violate discipline, any corporal punishment or corporal punishment in disguised form is considered as a tort. Pursuant to the Compulsory Educational Law, Teachers Law and the Law on Protection of Minors of China, no teachers shall exert corporal punishments on students. Educational punishment is an educational method with which teachers negatively crack down on any improper conduct of students in the process of education to avoid it arising again and contribute to the generation and consolidation of proper acts.

The related educational laws of China just vaguely accept the power of educational punishment without any provision for granting schools and teachers the power. According to Article 7(3) of the Teachers Law of the People's Republic of China, teachers shall be entitled to provide guidance on students' studies and development and assess students in

This is the final achievement of the "Investigation and Legal Study on Educational Punishments by Schools" for the 2015 Project of Scientific Planning Of Philosophical Social Science Education of Yunnan (Project No.: AC15012). terms of their conducts and academic achievements. Under Article 28 of the Educational Law of the People's Republic of China, schools and other educational institutions shall have the right to manage the school roll of their students and punish or reward them. According to Article 15 of the Primary School Management Regulation specified by the Ministry of Education, primary schools shall criticize the students making a mistake, and give warning, serious warning and demerits on record to a few students who make serious mistakes. In addition, in the process of educational practices, it is difficult to implement punishments on a fully moderate basis so that corporal punishments or corporal punishments in disguised form are formed to a certain extent. Therefore, punishment-related laws must be laid down to ensure punishments are exerted in a reasonable manner and educations go on well and safeguard the legal rights and interests of teachers and students.

\section{NECESSITY AND FEASIBILITY}

Although the current laws of China fail to definitely grant teachers the power of punishment, there have been many implied terms which agree that teachers shall have the power and the power is legitimate to a certain extent. If teachers are rationally and legitimately granted the power of punishment, it will be feasible to make laws on the power.

\section{A. Protect Students' Right to Education}

Any abuse of the power of punishment, especially any physical punishment physically and mentally hurting students, infringes students' personal rights. Under the international and national environment in which protection of personal rights is greatly encouraged, any abuse of the power of punishment breaks the spirit of international protection of personal rights and Article 28 of the Convention on the Rights of the Child which provides that "Contracting states shall take any appropriate measures to ensure schools enforce disciplines in a manner that respects children and complies with the Convention. For the purpose of caring for students, teachers shall exert any punishment in a form that respects students to avoid any negative impact on students. In addition, teachers shall stand in students' shoes, inspire students to examine themselves and timely praise the students who have made an improvement." This shows that teachers will infringe students' personal rights in case of failure to enforce punishments in any form that respects students. In China, any abuse of the power violates students' dignity and prevents the development of students' personality, body and mind. Therefore, it is necessary and 
feasible to adapt to the development of international personal rights and regulate the power of educational punishment by laws.

\section{B. Construct A Basis on Which Schools Manage Education}

In the absence of sound laws for primary and secondary school education in China, there are many such serious problems arising out of punishment as infringement of students' legal rights and interests, physically and mentally hurting students and revenge by students on teachers, and even some teachers dare not enforce punishments to protect themselves against any adverse consequence arising therefrom, thus leaving a chaos for education. The difficulties in punishment, supervision, protecting rights and managing schools resulting from legislative defects lead to an adverse impact on the healthy development of education. To better manage education, definition must be given to the legality of the power of punishment.

\section{Inspire by Overseas Laws on Educational Punishment}

A large number of foreign countries have made laws for the power of punishment and gained a good effect, which inspires China to follow and indirectly proves that it is feasible to make laws by China on the power of punishment. The Education and Inspections Act of the UK released in April 2006 definitely specifies teachers' power of punishment. 23 states of the U.S. have made the laws which definitely grant teachers the power to punish students and specifically provide the principle and mode of punishment. The Ministry of Education and Human Resources of Korea published the "School Rule Indication Program" on _ which allows teachers to physically punish students violating discipline to a certain extent, thus "legalizing" the physical punishment. First, the legal provisions deserve to be used for reference. The laws of the UK and the U.S. on the power of punishment define the purpose, principle, way and procedure of exercising the power and the related supervision and relief mechanism. Second, the countries who have made laws on teachers' power of punishment have gained an obvious effect and could ensure the healthy growth of students and a favorable teaching order.

\section{PRINCIPLE OF ENFORCING EDUCATIONAL PUNISHMENTS}

"Consideration should be given to the following for the purpose of properly exerting punishments: from the macroscopic point of view, in order to achieve disciplinal education, appropriate provisions should be given to those who enforce punishments, those to be punished and the procedure of punishment, and a particular punishment should be enforced by a particular subject (such as teacher, teacher group and headmaster). Only legal subjects could exercise the relevant power of punishment to ensure its legality. Punishments should be exerted on the misconducts of students instead of the students. Those exerted on the body, dignity, personality and soul are considered against education. Subject to a certain procedure, teachers should exercise the power of punishment or give educational punishments on the basis of the relevant principles[1]".
From the perspective of jurisprudence, schools and teachers exercise the power of punishment subject to the theory of law as the following principles must be adhered to:

- Legality. It means that schools and teachers must exercise any right or power on a legitimate basis, which is the most basic requirement for them to exercise the power of punishment. Schools and teachers can only punish the students who make a mistake, and should take punitive measures for definite and legitimate reasons, which should particularly comply with the national legal provisions instead of their own will. In addition, punishments should be enforced through such legitimate procedure that safeguards the right of students and their parents to know the reason why they are punished and prepares the basis of punishment on which students have the right to appeal and claim legal relief.

- Fairness. Schools and teachers should punish students on a fair and just basis without prejudice or arbitrary decision. However, in different cases, such as in the event of inborn heredity and any difference among students in family environment and personality, teachers should take appropriate punitive measures in the principle of fairness.

- Appropriateness. No punishments should infringe students' basic rights such as the personal right, the property right and the right to education. In particular, any punishment should be enforced in a manner that respect students' personality instead of any insulting or discriminatory manner that physically and mentally hurts students. Schools and teachers should make a judgment and deal with problems in combination with the specific situation, in accordance with the mental and physiological characteristics, the personality and particularity of students.

- Practicality. Specifically speaking, foreign experience should be learned to prepare a punishment-related document consistent with the Chinese conditions, in which definition should be given to the type of punishment to be given to students, those who should enforce punishments and the specific method and scope of punishment for different violations, thus gradually materializing and normalizing the punitive measures and making them more practicable to an extent that directs schools and teachers to properly exercise the power of punishment.

\section{METHODS OF ENFORCING EDUCATIONAL PUNISHMENTS}

In Taiwan, China, students are punished through two measures, including general disciplinary measure and disciplinary measure against major violations, of which the former contains persuasion to correct, oral advice to correct, cancellation of the right to take part in any activity beyond those in the curriculum schedule, coaching or directing students to correct after class, adjustment to seats, assignment of additional homework or works, deduction of 
students' conduct grade, request for an apology or a written statement of repentance and compensation for any damage to the public properties or others' belongings, and the latter contains warning, demerits, coaching on holidays, academic probation, transfer to another class or change in the learning environment, mandatory psychological guidance, submit to judiciary authorities to deal with and transfer to another school[2].

In Mainland China, legal punishments are prepared in the regulations of the Ministry of Education and in the local laws and regulations and the rules of local government. According to the Primary School Management Regulation specified by the State Education Commission in 1996, primary schools may give warning, serious warning and demerits on record to a few students who make a mistake. Such punishments are also included in the local laws and regulations and the rules of local government. In addition to the legal punishments, the Mainland China also provides a large number of disciplinary measures put into practical use, which are excluded in school rules but have been used in teaching management. In summary, such measures mainly include criticism, isolation, request for standstill and a written selfcriticism, retention, deprivation of a particular right, assignment of additional homework, request for doing something, sanitization and copying homework, communication with parents, confiscation of belongings, suspension of classes, posting a notice and request for selfcriticism in public.

Laws must be made to determine the above punishments and define the legitimate and prohibitive punishments. It is also necessary to quantize the methods and scope of punishment so as to facilitate operation and supervision in educational practices. For example, provisions must be made for such condition as breach of a specific discipline in which students could be requested to stand still in the event of breach of a kind of discipline, the location or place where and the length when they should stand still.

\section{APPROACH TO RELIEVE STUDENTS'RIGHT IN EDUCATIONAL PUNISHMENT}

Legislation should be further strengthened to ensure that students could relive their rights in a convenient and effective manner upon infringement of students' legal rights and interests by any educational punishment. Schools and teachers should explain why students should be punished, allow students to defend themselves and grant them the right of speech. Parents should also have the right to know any punishment of their children.

\section{Improvement should be made in terms of the following:}

First, make laws to normalize and refine the educational appealing system. The Educational Law of China definitely provides the student appealing system, by which students may appeal to a competent administrative authority against any infringement of their legal rights and interests according to the Law and other laws. However, it is worth noting that China needs a specific provision for the specific procedure of appeal and the relief approach in case of any objection against the judgment. Special laws and regulations should be released to define the basic principle in which the punished students may file a complaint, the scope, jurisdiction and procedure of appeal, the case in which the students may file or withdraw a compliant, compliant acceptance and handing manner and prescription so as to safeguard students' right to education and define the legal effect of the judgment and the legal responsibilities of the related authorities and personnel.

Second, prepare education mediation system. An independent intermediary should be built to deal with any complaint and thus ensure the impartiality, in combination with the experience of foreign countries in using a nonadministrative mediation organization for distinguishing and defining the power of punishment and resolving any dispute over exercising the power through necessary mediation or through initial arbitration if it fails.

Thirdly, improve the educational administrative review system. Since no definition has been legally given to the relationship between schools and educational institutions in China, it is difficult to normalize the relationship between rights and obligations in the educational administrative review activities. In the opinion of the author, we should further strengthen the construction of educational administrative review organs to ensure smooth administrative review. In addition, the organs should define the scope and procedure of educational administrative review and accept the legitimate applications for the review according to laws.

Fourthly, improve the educational administrative lawsuit system. Chinese courts are responsible for acceptance of civil lawsuits and administrative lawsuits. Schools and students or teachers may file a civil lawsuit against any civil legal dispute between them. Teachers are not allowed to file an administrative lawsuit against any administrative legal dispute between schools and students or teachers. Therefore, further improvement should be made to the lawsuit relief mechanism.

Finally, construct an educational arbitration system. Educational arbitration refers to such activities as conciliation and adjudication of any dispute between a student and its school by the special arbitration committee of education according to the educational laws upon receipt of an arbitration application from the student who objects against any response and punishment given by the school or considers that the school infringes its personal right and property right. In the absence of an educational arbitration system for legal relief of education in China, in consideration of its efficiency, justice and promptness, educational disputes may be resolved through revision to the related laws and regulations and arbitration by a special education arbitration institute which consists of experts in education and science of educational law like the way in which the labor dispute arbitration committee resolves labor disputes, thus safeguarding the rights of a party who stands in a weak position in an educational dispute in an effective and feasible manner. 


\section{CONCLUSION}

Separately making laws on the power of educational punishment requires a complicated legislative procedure, long period and considers greatly difficult. It is suggested to lay down national provisions to ensure teachers exercise the power of punishment on a standard basis, thus simplifying the procedure, shortening time and removing the adverse consequences arising from the absence of a basis on which teachers enforce punishments.

\section{REFERENCE}

[1] Tan Chuanbao. Educational Significance of Punishments and its Realization [J]. Journal of The Chinese Society of Education, 2004(2).

[2] Qin Mengqun. Educational Law and Legal Precedents of the U.S. [M]. Taipei Higher Education Press, 2004. 